九州大学学術情報リポジトリ

Kyushu University Institutional Repository

\title{
CORRECTION TO "SEQUENTIAL ESTIMATION OF A CONTINUOUS PROBABILITY DENSITY FUNCTION AND MODE"
}

Yamato, Hajime

Department of Mathematics, Faculty of Science, Kagoshima University

https://doi.org/10.5109/13067

出版情報: 統計数理研究. 15 (1/2)，pp. 133-133，1972-03. Research Association of Statistical Sciences

バージョン：

権利関係 : 


\title{
CORRECTION TO \\ "SEQUENTIAL ESTIMATION OF A CONTINUOUS PROBABILITY DENSITY FUNCTION AND MODE"
}

By

\author{
Hajime Yamato*
}

The sentence written from the 24-th line to the 27-th line on pp. 2 in the above paper [Bull. Math. Statist., Vol. 14 (1971), No. 3 4, pp. 1 12], “Their consideration over the statistical properties from point of view of the estimation theory, however, were only on its asymptotical uniform unbiasedness assuming the uniform continuity of the probability density function", is corrected as follows.

Their main results concerning the density estimation are

$$
\int\left|\hat{f}_{n}(\boldsymbol{x})-f(\boldsymbol{x})\right|^{2} d \boldsymbol{x} \stackrel{n}{\rightarrow} 0
$$

in probability and with probability one, respectively. The asymptotically uniform unbiasedness is shown for uniformly continuous density functions.

\footnotetext{
* Department of Mathematics, Faculty of Science, Kagoshima University, Kagoshima.
} 